\title{
Krystyna Szymankiewicz
}

Uniwersytet Warszawski

k.szymankiewicz@uw.edu.pl

Radosław Kucharczyk

Uniwersytet Warszawski

r.kucharczyk@uw.edu.pl

\section{MAPY MYŚLI JAKO NARZĘDZIE BADANIA REPREZENTACJI SPOŁECZNYCH WIELOJĘZYCZNOŚCI - PRZYPADEK PRZYSZŁYCH NAUCZYCIELI JĘZYKA FRANCUSKIEGO}

\author{
Mind maps as a tool for studying social representations of multilingualism: \\ the case of prospective teachers of French language
}

Mind mapping is primarily a learning technique based on creating pictorial notes (Buzan 2003). In the present article, mind maps were used as a tool for the study of social representations, so as to investigate a broad spectrum of ideas, beliefs, and values related to multilingualism. The study involved a group of French Philology students training to become teachers of the French language, and its aim was to determine the extent to which their initial representations of multilingualism were consistent with the theoretical assumptions of the Council of Europe's language policy. This policy encourages teachers of foreign languages to develop multilingual competence among students. The analysis of mind maps and the transcription of the group interview leads to the conclusion that the respondents show some areas of ignorance and stereotypical beliefs that should be reflected upon in the course of their further education preparing them to the teaching profession.

Keywords: multilingualism, mind maps, social representations, French language teacher training, multilingual competence

Słowa kluczowe: wielojęzyczność, mapy myśli, reprezentacje społeczne, kształcenie nauczycieli języka francuskiego, kompetencja różnojęzyczna 


\section{Wstęp}

Wielojęzyczność, od czasu pojawienia się Europejskiego Systemu Opisu Ksztatcenia Językowego (ESOKJ) w 2001 roku, stanowiąca dotychczas przedmiot badań głównie socjolingwistycznych i psycholingwistycznych, stała się zagadnieniem istotnym również dla glottodydaktyki. Wynika to z nowego, szerszego spojrzenia na proces uczenia się języka (czy raczej kolejnych języków) jako na pewną całość, w ramach której zachodzą istotne dla efektu uczenia się transfery wiedzy i umiejętności, co dobrze ujmuje koncepcja kompetencji różnojęzycznej przedstawiona w ESOKJ (2003: 116-118). Nauczyciele języka obcego są tym samym zachęcani, by nawiązywać do repertuaru językowego uczniów (może to być np. wykorzystanie znajomości języka angielskiego w nauce drugiego języka obcego w gimnazjum i liceum) oraz do kształtowania strategii transferu interlingwalnego i transferu uczenia się. To niewątpliwie poważne wyzwanie, które łączy się z koniecznością rewizji niektórych tradycyjnych przekonań i wyobrażeń, jakie nauczyciele mogą posiadać na temat procesu nauczania/uczenia się języka obcego. Dlatego wskazane wydaje się podjęcie refleksji nad reprezentacjami społecznymi wielojęzyczności już w ramach wstępnego kształcenia nauczycieli (por. Szymankiewicz i Kucharczyk, 2015). W niniejszym artykule pragniemy przedstawić diagnostyczny i edukacyjny wymiar takiej refleksji, przeprowadzonej przy pomocy techniki mapy myśli wśród studentów profilu metodycznego w Instytucie Romanistyki Uniwersytetu Warszawskiego. Zanim przejdziemy do omówienia przebiegu i wyników badania, przedstawimy technikę mapy myślowej, uzasadniając jej wybór jako narzędzia badawczego, a także przywołamy definicje kluczowych dla naszych rozważań pojęć reprezentacji społecznych i wielojęzyczności.

\section{Mapa myśli jako narzędzie badania reprezentacji społecznych}

Mapa myśli kojarzy się przede wszystkim z rozwijaną od lat 70. XX wieku przez psychologa Tony'ego Buzana techniką robienia notatek i obrazowego przedstawiania informacji w sposób wymagający aktywności obu półkul mózgowych i jednocześnie zgodny z naturalnym, nielinearnym i wielokierunkowym procesem myślowym, dzięki czemu zwiększa się skuteczność zapamiętywania informacji (Buzan, 2003). W jaki sposób tworzy się mapy myśli? W centrum kartki należy umieścić rysunek odpowiadający danemu zagadnieniu czy problemowi, a to dlatego, że „obraz natychmiast przyciąga wzrok, wywołuje liczne skojarzenia i łatwo zapada w pamięć" (Buzan, 2003: 94). Od centralnego pojęcia wyprowadzamy linie lub strzałki, przy których zapisujemy, a najlepiej ilustrujemy przy pomocy obrazków, główne skojarzenia, a od nich następne rozgałęzienia dal szych 
skojarzeń. Ważne jest stosowanie hierarchii pojęć, używanie kolorów, różnych rozmiarów elementów mapy, stosowanie wyraźnego pisma i rysunków.

Buzan (2003) wymienia wiele możliwych zastosowań map myśli - jako techniki robienia notatek, zapamiętywania/uczenia się, techniki rozwiązywania problemów, prowadzenia dziennika, planowania, rozwijania twórczego myślenia. Zwłaszcza grupowe tworzenie map myślowych pozwala znakomicie powiększyć sferę dostępnych skojarzeń, co prowadzi w efekcie do stworzenia przez „umysł zbiorowy” pełniejszego, wielowymiarowego obrazu analizowanego problemu oraz daje możliwość opracowania jego kreatywnych rozwiązań (Buzan, 2003: 159).

Chociaż mapy myśli, jak wspomniano powyżej, znajdują zazwyczaj zastosowanie jako technika uczenia się i nauczania, bywają wykorzystywane także w psychologii, edukacji i socjologii jako narzędzie badawcze, „pozwalające na przedstawienie wiedzy i reprezentacji danej jednostki lub grupy na dany temat" (Meier, 2007: 1). Podkreśla się przy tym, że mapy myśli umożliwiają przedstawienie złożonych obszarów wiedzy, zarówno uświadomionej, jak i nieuświadomionej (tamże). Tym samym mapa myśli może posłużyć do badania reprezentacji społecznych.

Reprezentacje społeczne to pojęcie będące przedmiotem różnorodnych koncepcji, zwłaszcza na gruncie psychologii społecznej (Moscovici, 1976) oraz socjologii (Jodelet, 1994). Ogólnie przyjmuje się, że oznacza ono „formę wiedzy społecznie wytworzoną i podzielaną, posiadającą zastosowanie praktyczne i przyczyniającą się do konstruowania rzeczywistości wspólnej dla danej społeczności" (tamże: 36). Reprezentacje społeczne służą (re)konstruowaniu i wyjaśnianiu rzeczywistości, jednocześnie wzmacniając tożsamość grupową. W swojej złożoności zawierają elementy poznawcze, ideologiczne, normatywne, afektywne, przekonania, postawy, opinie i wartości, które składają się na całościowe znaczenie. Mają też charakter dynamiczny zarówno pod względem społecznym, jak i psychologicznym, czyli podlegają ewolucji.

W perspektywie badawczej określanej jako teoria reprezentacji poznawczych dąży się zazwyczaj do opisania, „jak pojęcia i koncepcje powstałe na gruncie teorii naukowej są wykorzystywane w życiu codziennym, obiektywizowane i włączane w rutynowe działania" (Flick, 2011: 48). Badaniu reprezentacji społecznych służą najczęściej takie narzędzia badawcze, jak wywiad indywidualny lub grupowy oraz ankieta (Rubacha, 2008: 140, 173; Albarello, 2012: 86). Mapa myśli stanowi mniej popularną, aczkolwiek wartościową technikę, która posiada szereg zalet, zwłaszcza jeśli połączy się ją z wywiadem grupowym (Beckett, 2010). Analizie poddaje się wówczas zarówno treść mapy, jak i transkrypcję przeprowadzonego na jej podstawie wywiadu. Beckett (2010) podaje przykład zastosowania wyżej wymienionej mieszanej techniki w ramach projektu badawczego, którego celem było zbadanie, w jaki sposób 
dzieci w szkole podstawowej w Anglii postrzegają dzieci z niepełnosprawnością. W tym przypadku technika mapy myśli połączona z wywiadem w znacznym stopniu ośmieliła dzieci oraz pozwoliła im przedstawić wszelkie skojarzenia z problemem niepełnosprawności zarówno w sposób wizualny, jak i werbalny. Dzięki analizie treści, badacze zidentyfikowali trzy główne modele myślenia o niepełnosprawności - myślenie „medyczne”, myślenie w kategoriach „tragedii” oraz myślenie w kategoriach „ograniczeń” wiążących się z niepełnosprawnością. Należy sprecyzować, że w przeprowadzonym przez nas badaniu nie zastosowano w sposób klasyczny techniki zogniskowanego wywiadu grupowego, stanowiącego luźno prowadzoną rozmowę na podany przez moderatora temat w celu „sprowokowania respondentów do wyrażania różnorodnych opinii na dany temat" (Kvale, 2012: 126), ale poproszono osoby badane o ustne opisanie i zinterpretowanie wykonanych map myśli, a także o odpowiedź na ewentualne pytania prowadzącego badanie.

Wśród atutów mapy myśli wymienia się również to, że technika ta opiera się na burzy mózgów, co wymaga przełamywania barier umysłowych i otwartości w poszukiwaniu skojarzeń, pozwala też na uzewnętrznienie złożonych obszarów wiedzy, która nie zawsze jest uświadomiona (Meier, 2007).

Istnieją różne możliwości analizy mapy myśli, np. analiza treści ilościowa lub/i jakościowa (Beckett, 2010). Analiza ilościowa polega na zliczeniu kategorii występujących na mapach, przyjętych dla badania a priori lub wyróżnionych w jakościowej analizie treści. Analiza jakościowa dąży natomiast do identyfikacji poruszonych tematów i związanych z nimi pojęć, a następnie do uchwycenia relacji między nimi, na koniec zaś do interpretacji rozumienia danego zagadnienia przez uczestników badania. Co ważne, interpretacja znaczenia, jakie mapa posiada z punktu widzenia jej autorów, wymaga uwzględnienia znaczenia kontekstu, w jakim przeprowadzono badanie. Chodzi np. o przynależność osób badanych do danej instytucji i związane z tym role.

W przypadku naszego badania wybór metody mapy myśli wynikał ze wspomnianych już możliwości, jakie daje grupowe tworzenie mapy myślowej, w zobrazowaniu aktualnego stanu wiedzy i wyobrażeń na dany temat, zwłaszcza jeśli towarzyszy temu zadaniu refleksja i werbalna interpretacja map przez ich autorów (Meier, 2007). Za dodatkowy atut techniki mapy myśli uznaliśmy za Farrellem (2007:167) jej użyteczność dydaktyczną w kształceniu nauczycieli języka obcego. Otóż technika ta pozwala studentom wziąć pod uwagę alternatywne sposoby pojmowania danego zagadnienia, stając się punktem wyjścia do ewolucji wiedzy i przekonań na dany temat.

Przyjrzyjmy się teraz zagadnieniu, które będzie przedmiotem badanych reprezentacji społecznych w grupie przyszłych nauczycieli języka francuskiego, a mianowicie wielojęzyczności w kontekście glottodydaktyki. 


\section{Wielojęzyczność i kompetencja różnojęzyczna w nauczaniu/uczeniu się języków obcych}

Podejście zaproponowane przez ESOKJ promuje zjawisko wielojęzyczności, osadzając je w szeroko rozumianym kontekście edukacyjnym. Autorzy dokumentu odróżniają wielojęzyczność od różnojęzyczności. Pierwsze pojęcie określa znajomość kilku języków przez daną osobę lub współistnienie różnych języków na danym obszarze, podczas gdy różnojęzyczność jest traktowana jako zjawisko psycholingwistyczne. Jak zauważają twórcy ESOKJ (2003: 16), „pojęcie różnojęzyczności sięga dalej, wskazując na fakt, że kolejne doświadczenia językowe i kulturowe danego człowieka, począwszy od języka domu rodzinnego i szerszej społeczności aż po języki innych narodów [...], nie są gromadzone w postaci odrębnych modułów, lecz składają się na jedną, całościową kompetencję komunikacyjną, w której wszystkie te doświadczenia i języki wzajemnie się przenikają i na siebie wpływają".

Nie dziwi fakt, że pojęcia wielo- i różnojęzyczności często pojawiają się w dokumentach opisujących proces kształcenia językowego w Europie, zważywszy, że wielojęzyczność jest codziennością niemal każdego obywatela Unii Europejskiej. UE składa się z wielu państw, w obrębie których występują różne języki, mające różny status, wywodzące się z różnych rodzin językowych. Ponadto wielu obywateli UE mówi kilkoma językami albo w wyniku historii rodzinnej lub historii politycznej kraju bądź regionu, w którym żyją. Bardzo często mają kontakt z językiem innym niż ich ojczysty (Maurer, 2011: 63-64). Co więcej, wielojęzyczność warunkuje koherentne funkcjonowanie UE, zwłaszcza w kontekście wymian ekonomicznych i zawodowych. W literaturze przedmiotu podkreśla się również, że wielojęzyczność jest zjawiskiem normatywnym, czyli codziennym, dotyczącym dużej populacji. Jak zauważa Chłopek (2011: 24), „osoby monolingwalne należą na świecie do mniejszości”. Za osoby różnojęzyczne uważa się przy tym również osoby, które znają, oprócz języka narodowego, np. język regionalny czy język mniejszości narodowej, a niekoniecznie język obcy w tradycyjnym tego słowa znaczeniu.

Z punktu widzenia glottodydaktyki zajmowanie się wielojęzycznością to poszerzenie perspektywy badawczej polegające na pełniejszym uwzględnieniu roli kontekstu nauczania/uczenia się, zachodzących w nim relacji między językami oraz nastawień i motywacji uczących się wynikających ze statusu języków. Owo poszerzenie perspektywy niesie ze sobą dwie istotne konsekwencje. Pierwsza, wspomniana już we wstępie, to przyjęcie modelu nauczania/uczenia się języka obcego z wykorzystaniem zasobu posiadanych przez jednostkę kompetencji w innych językach, w tym w języku ojczystym, czyli uznanie wartości kompetencji różnojęzycznej uczniów i dążenie do jej rozwijania. Duże możliwości 
stwarzają w tym przypadku tzw. podejścia pluralistyczne, np. dydaktyka interkomprehensji czy dydaktyka zintegrowana (Candelier i in., 2007). Drugą konsekwencją nowej perspektywy jest porzucenie ideału kompetencji native speakera jako celu nauczania/uczenia się języka obcego przy jednoczesnym docenieniu funkcjonalności tzw. kompetencji cząstkowych uczącego się w jakimkolwiek języku (ESOKJ, 2003: 118). Wszystko to zarówno dla nauczyciela, jak i dla ucznia oznacza konieczność przewartościowania i przeorientowania tradycyjnych przekonań, jakie często żywią na temat celów i sposobów nauczania/uczenia się języka obcego. Znaczenia nabierają w tej sytuacji reprezentacje społeczne wielojęzyczności, gdyż od nich będzie zależeć zaangażowanie nauczycieli lub jego brak w dydaktykę wielojęzyczności i rozwijanie kompetencji różnojęzycznej uczniów.

\section{Badanie empiryczne: reprezentacje społeczne przyszłych nauczycieli języka francuskiego na temat wielojęzyczności i kompetencji różnojęzycznej}

\subsection{Przedmiot i cel badania}

Jak stwierdzono na początku artykułu, celem badania była diagnoza reprezentacji dotyczących zjawiska wielo-i różnojęzyczności wśród studentek, które planują zostać nauczycielkami języka francuskiego. Wcześniejsze badanie przeprowadzone przez autorów niniejszego artykułu wykazało, że studenci kończący specjalizację nauczycielską w IR UW według dawnych wytycznych ministerialnych posiadali wiedzę teoretyczną związaną z wielojęzycznością oraz kompetencją różnojęzyczną, a także prezentowali pozytywne nastawienie do rozwijania tej kompetencji na lekcjach języka francuskiego (Szymankiewicz i Kucharczyk, 2015). Ciekawe wydało się więc zbadanie, jak tę kompetencję postrzegają studentki rozpoczynające swoją przygodę z dydaktyką i czy widzą dla niej miejsce na lekcjach języka francuskiego, które niebawem będą prowadziły w ramach praktyk pedagogicznych. Uznaliśmy ponadto, że przeprowadzenie badania reprezentacji społecznych przyszłych nauczycieli języka francuskiego na temat wielojęzyczności to potrzebny element początkowej edukacji nauczycielskiej. Mamy bowiem do czynienia z zagadnieniem aktualnym, ale nieoczywistym dla mieszkańców kraju monolingwalnego. Co za tym idzie, dotychczasowa wiedza studentów na temat wielojęzyczności i kompetencji różnojęzycznej może być niewystarczająca dla przyszłej praktyki rozwijania kompetencji różnojęzycznej u uczniów po podjęciu pracy w szkole. W tej sytuacji rozpoznanie reprezentacji społecznych i refleksja nad nimi podczas kształcenia metodycznego niesie ze sobą wartość nie tylko diagnostyczną, ale również edukacyjną jako pierwszy krok ku ewentualnej modyfikacji wyobrażeń i przekonań. 


\subsection{Próba badawcza}

Badanie, którego wyniki zostaną przedstawione poniżej, zostało przeprowadzone wśród studentek Instytutu Romanistyki UW (N=20) uczęszczających na zajęcia specjalizacji nauczycielskiej. Wśród nich przeważały osoby studiujące na II roku studiów licencjackich; kilka studiowało na I roku studiów magisterskich ${ }^{1}$. Dopiero rozpoczęły realizację ścieżki dydaktycznej i nie miały do chwili badania żadnych zajęć związanych w wielojęzycznością w kontekście glottodydaktycznym. Można więc przyjąć, że na sposób postrzegania wielojęzyczności w przypadku badanej próby rzutowało przede wszystkim zdobywane wykształcenie filologiczne oraz doświadczenia w uczeniu się języków obcych w polskim systemie szkolnictwa.

\subsection{Przebieg badania}

Badanie zostało przeprowadzone w semestrze letnim 2014/2015, w czasie zajęć z „Dydaktyki nauczania języka francuskiego w przedszkolu i klasach 1-3 SP”. W pierwszej kolejności studentki uczestniczące w zajęciach zostały podzielone na cztery grupy. Każda z grup miała za zadanie narysować mapę myśli wokół obrazka przedstawiającego dziecko wielojęzyczne, a następnie zaprezentować ustnie swoją pracę pozostałym grupom. Tworzenie map myśli było ukierunkowane następującymi pytaniami:

- Jak można zostać osobą wielojęzyczną?

- Jakie są zalety i wady bycia osobą wielojęzyczną?

- Jak osoba wielojęzyczna uczy się kolejnych języków obcych?

- Jak osoba wielojęzyczna wykorzystuje swój język ojczysty/swoje języki ojczyste w nauce języków obcych?

- Jak osoba wielojęzyczna zachowuje się w czasie komunikacji, gdy głównym językiem wymiany jest język inny od jej języka ojczystego/języków ojczystych?

Następnie każda grupa prezentowała i omawiała stworzoną mapę myśli, odwołując się do powyższych pytań, zaś prowadzący badanie zadawał pytania

\footnotetext{
${ }^{1}$ Od roku akademickiego 2013/2014 kształcenie nauczycieli w IR UW zostało przystosowane do nowych wytycznych ministerialnych. Na studiach 1. stopnia studenci uzyskują uprawnienia do nauczania języka francuskiego w przedszkolu i szkole podstawowej, natomiast na studiach 2. stopnia uprawnienia do nauczania na pozostałych etapach edukacyjnych. Modułowe zajęcia z zakresu dydaktyki przedmiotowej są tematycznie związane z profilem psychopedagogicznym danej grupy wiekowej. Studenci, którzy nie uzyskali uprawnień pedagogicznych na 1. stopniu, a chcą ukończyć specjalność nauczycielską, są zobowiązani do uczęszczania na obydwie ścieżki w czasie studiów magisterskich.
} 
dodatkowe. Wypowiedzi studentek zostały nagrane na nośniku cyfrowym, co pozwoliło na dokonanie analizy jakościowej transkrypcji.

\section{Analiza map myśli i transkrypcji werbalnych objaśnień}

\subsection{Struktura map myśli}

Jak można zauważyć na zamieszczonych poniżej zdjęciach map myśli, tylko grupa 3 opracowała mapę hierarchiczną. Pozostałe grupy stworzyły kolorowe mapy prezentujące napisy i dopełniające je obrazki w sposób mniej uporządkowany, jako rezultat spontanicznego, grupowego kodowania skojarzeń nasuwających się członkom danej grupy podczas burzy mózgów. Jednak, jak się przekonamy, ustna interpretacja podana przez autorki mapy odsłania relacje logiczne między elementami i pozwala określić reprezentacje społeczne wielojęzyczności.

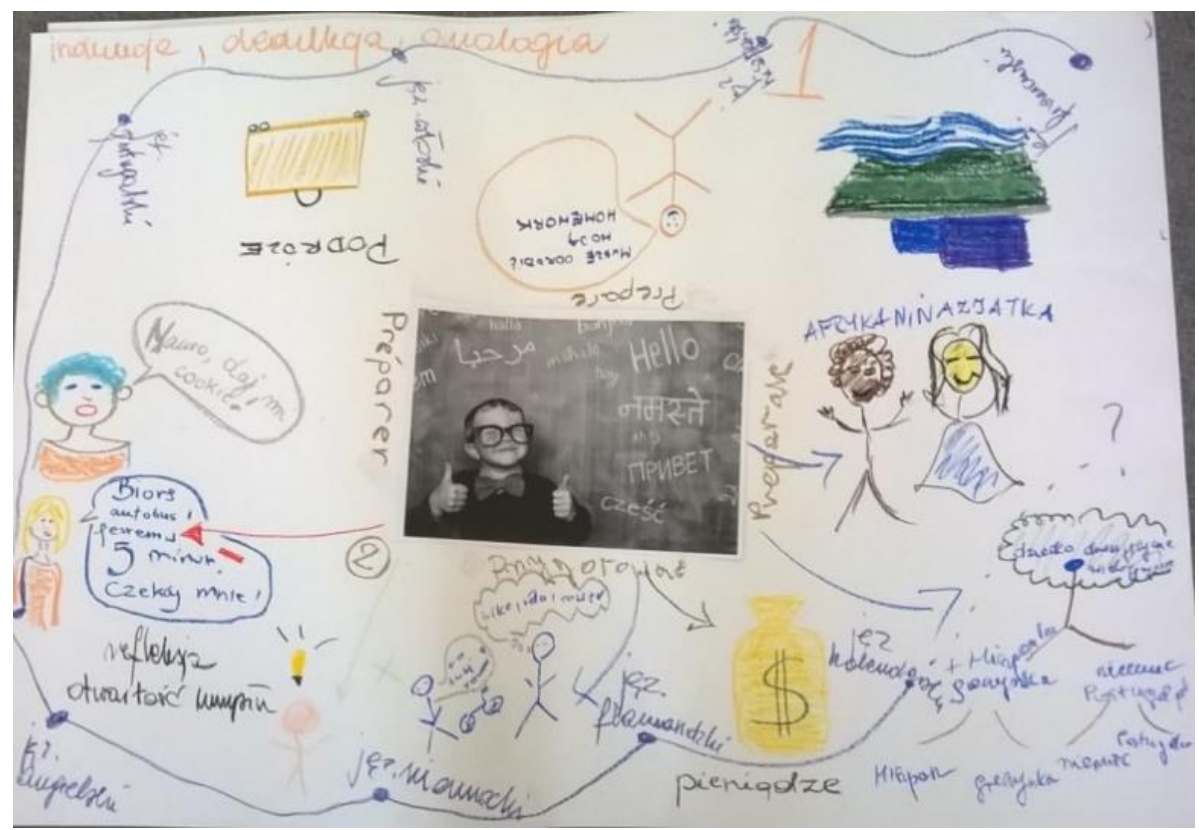

Zdjęcie1: Mapa myśli - grupa 1. 
Mapy myśli jako narzędzie badania reprezentacji społecznych wielojęzyczności...

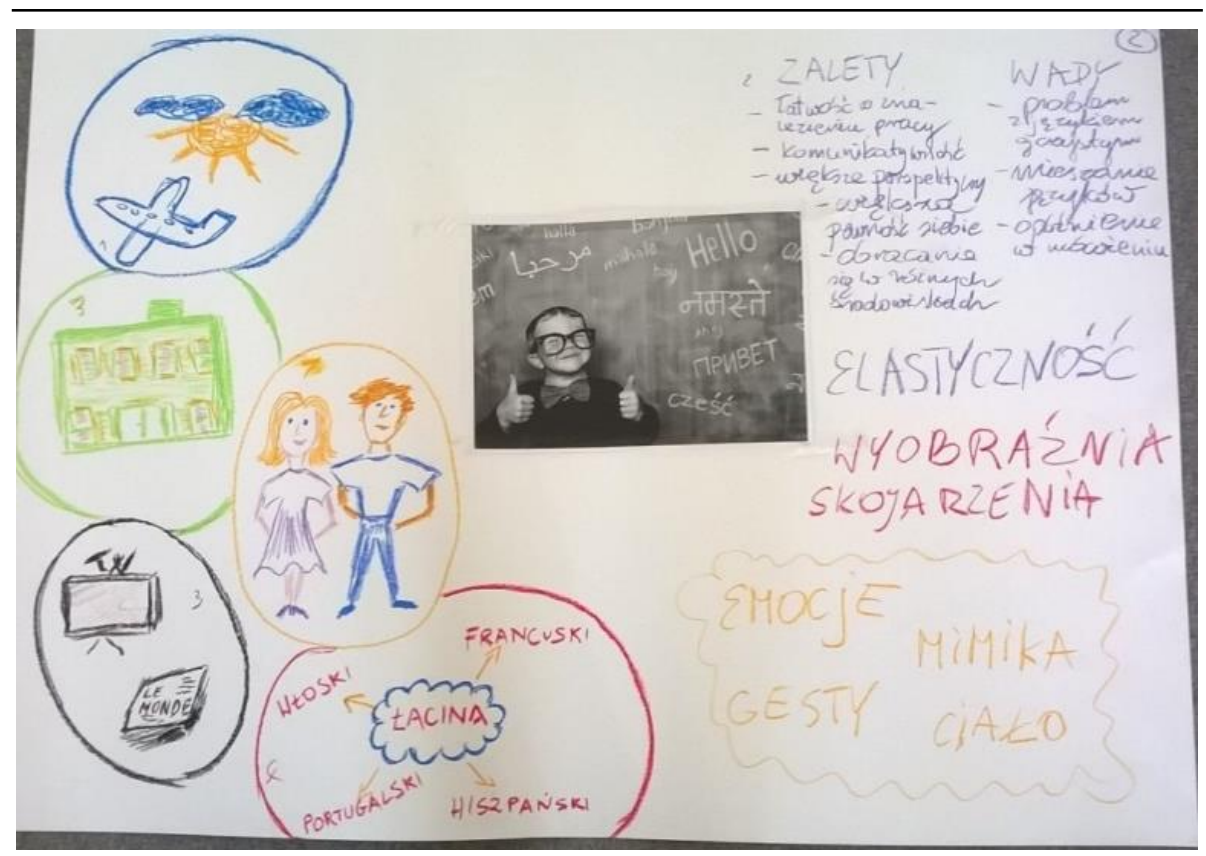

Zdjęcie 2: Mapa myśli - grupa 2.

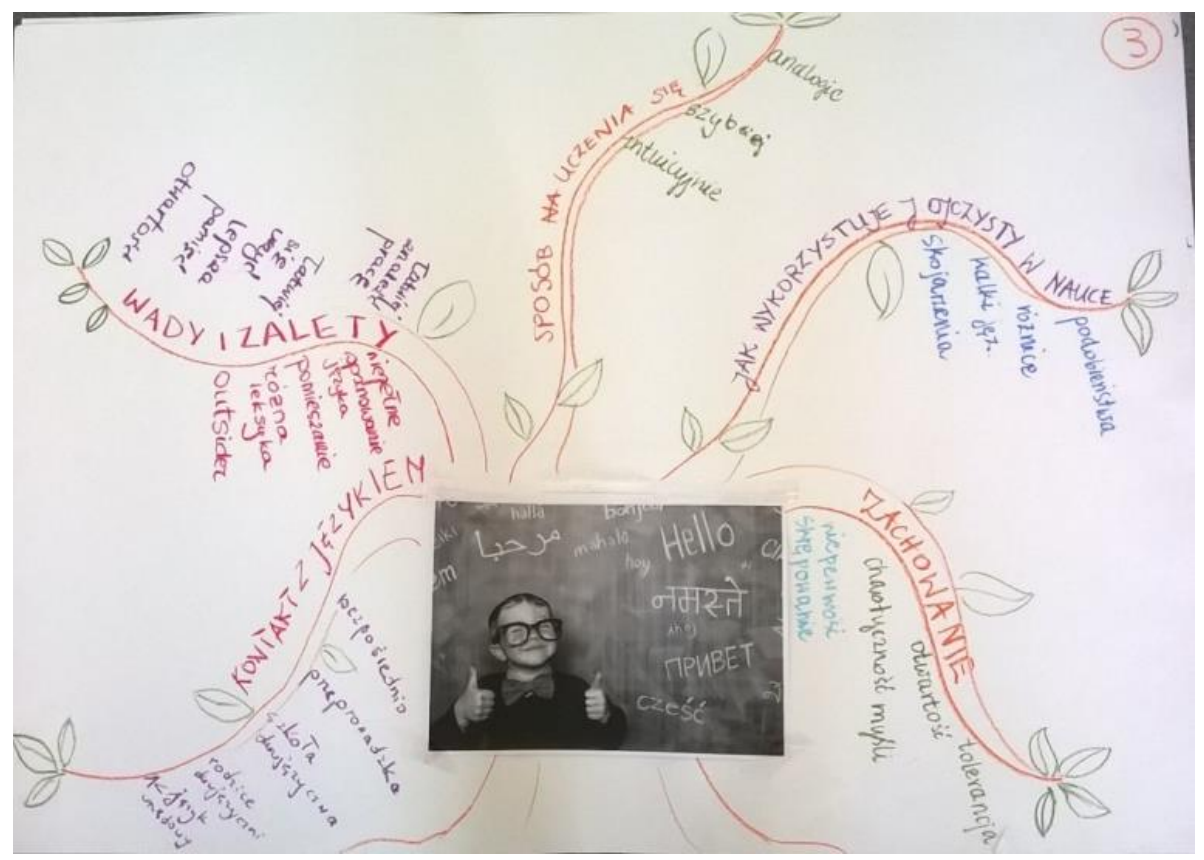

Zdjęcie 3: Mapa myśli - grupa 3. 


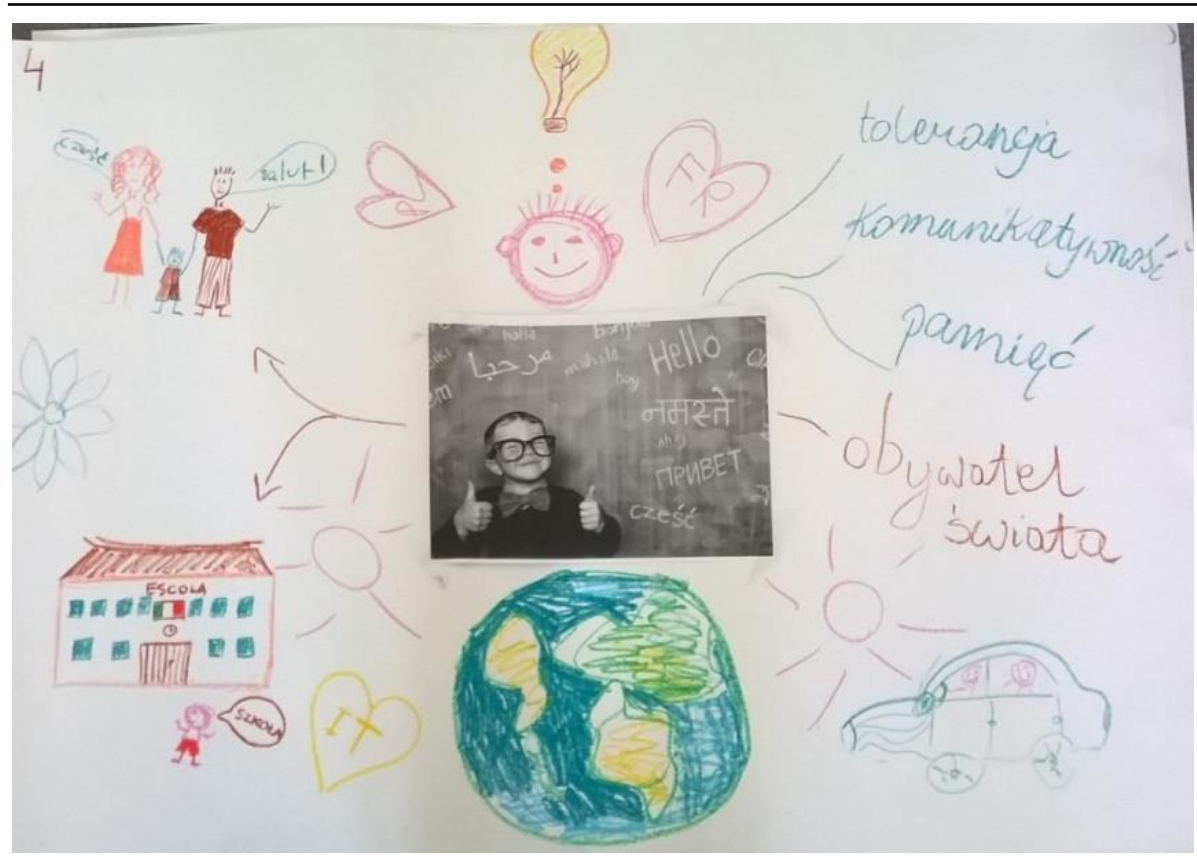

Zdjęcie 4: Mapa myśli - grupa 4.

\subsection{Analiza treści}

Czego zatem możemy się dowiedzieć z map myśli oraz wypowiedzi ustnych na temat reprezentacji wielojęzyczności u badanych studentek? Przedstawimy główne punkty reprezentacji społecznych według pytań, na które studentki miały poszukiwać odpowiedzi, rysując i omawiając mapy myśli.

\subsubsection{Jak można zostać osobą wielojęzyczną?}

Według studentek wielojęzyczność jest przede wszystkim wynikiem wielokulturowości w rodzinie lub życia w środowisku wielojęzycznym, co obrazują rysunki par mieszanych narodowościowo i budynek zagranicznej szkoły. Studentki komentują ten punkt następująco:

„Osobą wielojęzyczną można zostać przez urodzenie, tak? Będąc w rodzinie wielojęzycznej". (G2)

„Poprzez podróże czy wyjeżdżając z rodzicami za granicę i chodząc do szkoły”. (G2) 
„Mamy drzewo takie jak genealogiczne, gdzie jest dużo... dużo, jakby to powiedzieć... ramion jeśli chodzi o pochodzenie, np. mama Greczynka, która ma pochodzenie - nie wiem - jest pół-Amerykanką, pół-Mongołką i tak dalej”. (G1)

„No, oczywiście rodzice wielojęzyczni, tak jak to było już powiedziane. Albo w naszym kraju jest używanych więcej języków niż jeden, że inne języki urzędowe są bardziej rozwinięte". (G3)

„Więc, jak zostać osobą wielojęzyczną, to już zostało powiedziane: albo przez rodziców/rodzinę, albo też przez szkołę. Tutaj w ten sposób chciałyśmy pokazać to, że osoba jakiejś tam narodowości mieszka w innym kraju, nie w tym, z którego pochodzi i uczęszcza do tej szkoły.

Prowadzący: Dlatego szkoła po włosku jest napisane?

- Tak, tak". (G4)

Z zagranicznymi pobytami wiążą się podróże, symbolizowane przez walizkę i statek (grupa 1), samolot (grupa 2) oraz samochód (grupa 4).

Innym warunkiem osiągnięcia przez jednostkę wielojęzyczności, w ocenie studentek, jest posiadanie odpowiednich zasobów finansowych, by uczyć się na kursach językowych, co symbolizuje worek z dolarami (grupa 1).

Z powyższych stwierdzeń wynika, że bycie osobą wielojęzyczną w kraju monolingwalnym, jakim jest Polska, należy do rzadkości, i wymaga raczej uczenia się w środowisku zagranicznym (podróże, edukacja szkolna w innym kraju) lub specjalnych nakładów finansowych i czasowych, koniecznych w przypadku uczestnictwa w kursach językowych. Co ciekawe, ani razu nie wymieniono możliwości rozwinięcia wielojęzyczności poprzez naukę języków obcych w polskiej szkole. Można stąd wnioskować, że dla studentek wielojęzyczność jest zjawiskiem rzadkim i wyjątkowym, niemożliwym do osiągniecia w ramach krajowej edukacji szkolnej.

\subsubsection{Jakie są zalety i wady bycia osobą wielojęzyczną?}

Do zalet bycia osobą wielojęzyczną studentki zaliczają otwartość na inność językową i kulturową, lepszą pamięć, większą komunikatywność i wyobraźnię, a w ślad za tym - łatwość podróżowania i atrakcyjność na rynku pracy.

„Wyrobioną refleksję na temat życia i otwartość umysłu”. (G1)

„No akceptujemy te zmiany i akceptujemy innych, którzy też są dwujęzyczni. Jesteśmy otwarci na inne kultury. Łatwiej nam poznać też inne kultury dzięki temu, że znamy inne języki”. (G3)

„Tolerancja, komunikatywność, pamięć - lepsza pamięć - chodzi o to, że jeśli wcześniej zaczynamy się uczyć języka, może to wpływać na pewno na naszą późniejszą naukę. No, osoba wielojęzyczna jest obywatelem świata, jest otwarta. 
Prowadzący: Co to znaczy „być obywatelem świata”?

- To znaczy dobrze się czuć i funkcjonować w różnych środowiskach, w różnych krajach, w różnych miejscach. No więc na pewno podróże, praca, to są te argumenty takie podstawowe. I kreatywność". (G4)

„To tak: łatwość znalezienia pracy, komunikatywność, szersza perspektywa w znalezieniu pracy, większa pewność siebie, obracanie się w różnych środowiskach - to są takie zalety tego. No i jest większa elastyczność". (G2)

„Poza tym jest większa - to są zalety jeszcze tak? - wyobraźnia. Ponieważ trzeba sobie ten język, ktoś, kto uczy się języka, trzeba go sobie wyobrazić. Trzeba sobie wyobrazić słowa, więc... no i oczywiście skojarzenia, on mają one są powiązane. Jeżeli chodzi tutaj o tą chmurkę/górkę tu, to ona przedstawiona jest rzeczy/emocje, które wspomagają wyrażanie się, wspomagają język. Bo nie tylko używamy samych słów, ale również wspomagamy je ciałem". (G2)

Wśród wad bycia osobą wielojęzyczną studentki najbardziej zdaje się niepokoić niebezpieczeństwo mieszania języków i formułowania niepoprawnych wypowiedzi oraz opóźnienia rozwoju mowy u dzieci wzrastających w środowisku wielojęzycznym.

„Mamy też takie najpopularniejsze teksty, co wiąże się... to znaczy przykłady, które wiążą się z wadami wielojęzyczności, a także problemami, które ma osoba wielojęzyczna, np.: »biorę autobus i jestem w pięć minut, czekaj mnie«, albo »mamo, daj mi kuki«, albo »muszę zrobić moją homework«". (G1)

„Wady - no to problem z językiem ojczystym, bo czasami jest tak, że dzieci później zaczynają mówić, dzieci w rodzinach wielojęzycznych. One przysłuchują się i dopiero później, w stosunku do dzieci używających jeden język, zaczynają mówić. Wynika to z mieszania tych języków. No i później opóźnionie mówienie, tu jest zaznaczone". (G2)

Pojawiają się w związku z powyższym obawy o akceptację społeczną i poczucie tożsamości dzieci wielojęzycznych.

„No, istnieje ryzyko, że nie poznamy jednego języka w stopniu takim zadowalającym, będziemy go mieszać. Albo jesteśmy wykluczeni może też przez społeczeństwo w pewien sposób, przez to pomieszanie języków". (G3)

„Co do minusów, to może w przypadku dzieci, to co już powiedziała koleżanka, na pewno w jakimś stopniu wyobcowanie, bądź też czasami pewne zatracanie się tożsamości. Bo może to dziecko tak naprawdę nie wiedzieć kim jest i skąd pochodzi, jeżeli część życia spędziło tu, część tu i jeszcze ulegając jakimś tam presjom społecznym dzieci". (G4) 
Studentki z grupy 1. posuwają się nawet do spojrzenia na wielojęzyczność jako zagrażającą zdrowiu psychicznemu:

„Ale z drugiej strony to może też prowadzić do jakiejś depresji, albo może mieć znaczne problemy $w$ wypowiadaniu się $w$ danym języku... taka nadmierna refleksja do życia, zastanawianie się nad każdym... nie wiem... nad każdym problemem, prowadzi do tego, że się tak $w$ to zapętlamy i możemy potem 10 lat terapii i Tworki". (G1)

Wydaje się, że wyobrażenia dotyczące plusów i minusów bycia osobą wielojęzyczną nie opierają się na osobistych doświadczeniach studentek, w niewielkim stopniu być może wynikają z wiedzy naukowej (mieszanie języków), a przede wszystkim wypływają z naiwnej wiedzy zdroworozsądkowej (psychiczne skutki mieszania języków).

\subsubsection{Jak osoba wielojęzyczna uczy się kolejnych języków obcych? Jak osoba wielojęzyczna wykorzystuje swój język ojczysty/swoje języki ojczyste w nauce języków obcych?}

Jeśli chodzi o sposób uczenia się kolejnych języków, to studentki wskazują na możliwość wykorzystania znajomości języka lub języków do nauki kolejnych języków poprzez transfer pozytywny. Wymieniają tutaj proces analogii, poszukiwania podobieństw i skojarzeń.

„Osoba, która uczy się kolejnych języków, działa na zasadzie skojarzeń i np. przyłącza do prepare - preparare, albo prepare i wie, że to znaczy przygotować. I to jest raczej pozytyw". (G1)

„No chodzi o to, że język, jeżeli się zna różne języki, one... uczy się ich poprzez skojarzenia z językiem... w zasadzie wszystkie języki, wszystkie może nie, ale np. grupa języków romańskich wywodzi się z łaciny. Słowa są podobne, więc można się wspomagać różnymi językami. Szczególnie, jeżeli np. uczymy się któregoś z tych języków łacińskich". (G2)

„A jak pomaga wielojęzyczność w nauce kolejnych języków? No to na pewno ją ułatwia, bo patrzymy przez pewien pryzmat, przez pewne schematy, czy to gramatyki, czy słówek, szukamy podobieństw. Jeżeli nasz język jest z tej samej grupy, jeżeli z innej to też są czasem podobieństwa". (G4)

„Jakie są sposoby na uczenie się? No to jest analogia, przekładamy z jednego języka do drugiego, stosujemy kalki językowe. Na pewno szybciej przystosowujemy kolejny język. Jesteśmy bardziej intuicyjni”. (G3) 
Płynność i łatwość nauki w rodzinie wielojęzycznej lub w środowisku wielojęzycznym na rysunku grupy 1 . symbolizuje wąż:

„I on się wije od francuskiego poprzez hiszpański, włoski, portugalski. W taki sposób według nas uczy się dziecko od początku kolejnych języków. Przez indukcję, dedukcję, to zależy od pomysłu, przez analogię". (G1)

Wymieniono też stosowanie strategii samodzielnego uczenia się, zilustrowane rysunkiem książek, gazet i telewizora:

„Poprzez słuchanie... słuchanie telewizji, czytanie gazet”. (G2)

\title{
5.2.4. Jak osoba wielojęzyczna zachowuje się w czasie komunikacji, gdy głównym językiem wymiany jest język inny od jej języka ojczystego/języków ojczystych?
}

Choć studentki przypisują osobom wielojęzycznym ogólnie większą komunikatywność i otwartość, to wyobrażenie o zachowaniu takiej jednostki w komunikacji uwzględnia wpływ innych czynników niż wielojęzyczność, zwłaszcza o charakterze osobowościowym. Studentki unikają tutaj uproszczeń:

\begin{abstract}
„Ale jeżeli chodzi o zachowanie się w czasie komunikacji w tym innym języku, no to to jest bardziej cecha osobowościowa. Nie ma znaczenia czy jesteśmy jednojęzyczni, czy wielojęzyczni. Tutaj są bardziej te uwarunkowania osobowościowe, to może wpływać na naszą otwartość $i$ tolerancję, ale z drugiej strony możemy być bardziej zamknięci w sobie przez to, że znamy te języki. Może nam to jednak sprawiać pewne ograniczenie". (G3)

„Zakładam raczej, że jest otwarta i chętna, i chce się komunikować, chociaż wiadomo, że czasami są wyjątki. No chyba nie można powiedzieć, że osoba wielojęzyczna jest zawsze tolerancyjna, komunikacyjna i otwarta. Czasami zostaje przymuszona do nauki języka, mimo to że nie chce się komunikować z innymi, więc myślę, że nie budowałaby takich relacji". (G4)
\end{abstract}

Na koniec rozmowy na temat przedstawionych map myśli studentki zostały dodatkowo zapytane o to, czy same uważają się za osoby wielojęzyczne. Tylko 6 osób z 20 badanych nazwałoby siebie osobą wielojęzyczną, podając jako uzasadnienie kryterium funkcjonalne, jak w poniższej wypowiedzi:

„Ponieważ jak wyjeżdżam gdzieś za granicę, czy do Francji czy do Anglii, za każdym razem mam łatwość komunikacji. Poza tym nawet jak kogoś na ulicy w centrum, w Warszawie spotkam, kto pyta w języku francuskim czy angielskim, gdzie znajduje się Pałac Kultury, to bez problemu jestem w stanie przeskoczyć na umiejętność i wytłumaczyć". 
Dla pozostałych studentek wielojęzyczność oznacza raczej bardzo dobrą znajomość każdego z języków, a nie umiejętność porozumienia się w typowych sytuacjach komunikacyjnych:

„Nie, nie uważam się [za osobę wielojęzyczną], dlatego że jedynym językiem, w którym się dobrze rozumiem jest francuski, oprócz polskiego tak. Rosyjski tam znam, angielskiego trochę się uczę, ale generalnie nie jest to na takim poziomie".

\section{Podsumowanie}

Zastosowanie mapy myśli wraz z ich ustnym omówieniem pozwoliło nam odkryć reprezentacje społeczne wielojęzyczności w badanej grupie studentek, stanowiące dla tych ostatnich jednocześnie okazję do refleksji i dyskusji nad zagadnieniem wielojęzyczności.

Badane przyszłe nauczycielki języka francuskiego wydają się w większości podzielać reprezentacje społeczne dotyczące wielojęzyczności w następujących punktach:

- przekonanie, że bycie osobą wielojęzyczną jest raczej zjawiskiem pozytywnym;

- wiedza na temat korzyści poznawczych (pamięć, komunikatywność i wyobraźnia) i pragmatycznych (podróże, praca) płynących z faktu bycia osobą wielojęzyczną;

- wiedza na temat trudności związanych z wielojęzycznością (mieszanie języków);

- wiedza metajęzykowa (istnienie rodzin języków, zjawiska transferu);

- wiedza na temat strategii uczenia się języków;

- wiedza na temat możliwości transferu uczenia się i strategii uczenia się języków;

- $\quad$ przekonanie, że osoba wielojęzyczna powinna znać poszczególne języki w stopniu doskonałym;

- przekonanie, że wielojęzyczność jest zjawiskiem rzadkim w Polsce;

- brak skojarzeń wielojęzyczności z nauką kilku języków w polskiej szkole;

- przekonanie, że warunkiem stania się osobą wielojęzyczną jest bezpośredni, intensywny kontakt $z$ językiem w wielojęzycznym środowisku rodzinnym lub szkolnym, ewentualnie udział w prywatnych kursach językowych.

Można przypuszczać, że elementy wiedzy dotyczącej języków i ich uczenia się funkcjonują w reprezentacjach wielojęzyczności za sprawą kształcenia filologicznego, jakie jest udziałem osób badanych. Natomiast przekonania na temat warunków osiągnięcia wielojęzyczności jednostkowej wydają się mieć 
charakter stereotypowy, wskazujący na brak osobistych doświadczeń w tym zakresie. Przekonania te są nieraz niezgodne z koncepcją dydaktyki wielojęzyczności promowaną przez Radę Europy w ESOKJ. Przykładowo osoby badane wydają się być przywiązane do wyidealizowanego modelu perfekcyjnej wielojęzyczności, której nie da się osiągnąć w warunkach nauczania szkolnego, gdy, jak już podkreślaliśmy, rozwijanie kompetencji różnojęzycznej oznacza odejście od modelu native speakera, uznanie wartości kompetencji cząstkowej i - przy odpowiednim wsparciu ze strony nauczycieli języków obcych możliwość rozwoju różnojęzycznego w ramach edukacji szkolnej. Z pewnością ten element opisanych reprezentacji społecznych będzie mógł zostać poddany dalszej refleksji i dyskusji w ramach wstępnej edukacji nauczycielskiej.

Przedstawione $w$ artykule badanie dało impuls do pogłębienia dociekań na temat wiedzy, przekonań i wartości związanych z rozwijaniem wielojęzyczności w tej samej grupie studentek. Kolejne dane, zebrane tym razem przy pomocy ankiety oraz wypowiedzi autonarracyjnej, mamy nadzieję, pozwolą nam w następnych publikacjach poszerzyć i uzupełnić wnioski z obecnej analizy.

\section{BIBLIOGRAFIA}

Albarello L. 2012. Apprendre à chercher. Bruxelles: De Boeck.

Beckett A. 2010. „Exploring Mind-Mapping as a Research Tool: from application to analysis”. Wykład wygłoszony podczas konferencji „Thinking Critically About Analysis", University of Leeds, 13.09.2010. [online: http://www.sociology.leeds. ac.uk/assets/files/research/events/A\%20Beckett\%281\%29.pdf; DW: 10.06.2015].

Buzan, T., Buzan, B. 2003. Mapy Twoich myśli. tódź: Wydawnictwo Ravi.

Candelier, M. (i in.). 2007. CARAP Cadre de Référence pour les Approches Plurielles des Langues et des Cultures. Conseil de l'Europe.

Chłopek, Z. 2011. Nabywanie języków trzecich i kolejnych oraz wielojęzyczność. Aspekty psycholingwistyczne (i inne). Wrocław: Wydawnictwo Uniwersytetu Wrocławskiego.

Europejski System Opisu Kształcenia Językowego: uczenie się, nauczanie, ocenianie. 2003. Warszawa: Wydawnictwa CODN.

Farrell, T. 2007. Reflective Language Teaching: From Research to Practice. London: Bloomsbury Academic.

Flick, U. 2011. Projektowanie badania jakościowego. Warszawa: PWN.

Jodelet, D. 1994. Les représentations sociales. Paris: PUF.

Kvale, S. 2012. Prowadzenie wywiadów. Niezbędnik badacza. Warszawa: PWN.

Maurer, B. 2011. Enseignement des langues et construction européenne. Le plurilinguisme, nouvelle idéologie dominante. Paris: Éditions des archives contemporaines.

Meier, P. S. 2007. „Mind-mapping - a tool for eliciting and representing knowledge held by diverse informants". Social research Update, 52: 1-4. [online: http://www. soc.surrey.ac.uk/sru; DW: 15.06.2015].

Moscovici, S. 1976. La psychanalyse, son image et son public. Paris: PUF. 
Mapy myśli jako narzędzie badania reprezentacji społecznych wielojęzyczności...

Rubacha, K. 2008. Metodologia badań nad edukacjq̨. Warszawa: Wydawnictwa Akademickie i Profesjonalne.

Szymankiewicz K., i R. Kucharczyk. 2015. „Kompetencja różnojęzyczna w początkowym kształceniu nauczycieli języka obcego". Neofilolog, 45(1): 73-86. 